\title{
Rheology, Microstructure, and Functionality of Low-Fat Iranian White Cheese Made with Different Concentrations of Rennet
}

\author{
A. Madadlou, ${ }^{1}$ A. Khosroshahi, ${ }^{2}$ and M. E. Mousavi ${ }^{1}$ \\ ${ }^{1}$ Department of Food Science and Engineering, Faculty of Agricultural Biosystem Engineering, \\ University of Tehran, Iran \\ ${ }^{2}$ Department of Food Science and Technology, Faculty of Agricultural Engineering, \\ University of Urmia, Iran
}

\begin{abstract}
A batch of full-fat (23\% target fat) and 3 batches of low-fat (6\% target fat) Iranian white cheese with different rennet concentrations (1-, 2-, and 3-fold the normal usage) were produced to study the effect of fat content reduction and promoted proteolysis on the textural and functional properties of the product. Cheese samples were analyzed with respect to their rheological parameters (uniaxial compression and small amplitude oscillatory shear), meltability, microstructure, and sensory characteristics. Reduction of fat content from 23 to $6 \%$ had adverse effects on the texture, functionality, cheese-making yield, and sensory characteristics of Iranian white cheese. Fat reduction increased the instrumental hardness parameters (storage modulus, stress at fracture, and Young's modulus of elasticity), decreased the cheese meltability and yield, and made the microstructure more compact. Doubling the rennet concentration reduced values of instrumental hardness parameters, increased the meltability, and improved the sensory impression of texture. Although increasing the rennet concentration to 2 -fold the normal usage resembled somewhat the low-fat cheese to its full-fat counterpart, it appeared to cause more reduction in yield. Increasing the rennet concentration 3 -fold the normal usage produced a product slightly more elastic than the low-fat cheese with normal concentration of rennet. Increasing the rennet concentration to 2 -fold the normal usage was useful for improving the textural, functional, and sensory properties of low-fat Iranian white cheese. (Key words: Iranian white cheese, low fat, rheology, microstructure)
\end{abstract}

Abbreviation key: $\mathbf{F F C}=$ control full-fat cheese, $\mathbf{G}^{\prime}=$ elastic modulus, IMCU = international milk clotting units, LFC1C = control low-fat cheese with normal concentration of rennet, $\mathbf{L F C 2 C}=$ low-fat cheese with dou-

Received March 30, 2005.

Accepted May 12, 2005.

Corresponding author: A. Madadlou; e-mail: ashkan.madadlou@ gmail.com. ble concentration of rennet, $\mathbf{L F C 3 C}=$ low-fat cheese with triple concentration of rennet, MNFS = moisture in nonfat substance, $\mathbf{M}: \mathbf{P}=$ ratio of moisture to protein .

\section{INTRODUCTION}

Fat reduction in the diet is important based on the scientific evidence linking diets that are high in fat to obesity, arteriosclerosis, coronary heart disease, elevated blood pressure, tissue injury, and certain types of cancer (Rudan et al., 1999; Guinee and Law, 2002). Hence, dietary fat intake reduction is an effective means of decreasing the risk of coronary heart disease (Hynes et al., 2001) and the other mentioned health problems. Reduced-fat dairy products are the most widely consumed reduced-fat foods (Drake et al., 1996); among these, the production of reduced- and low-fat cheese has significantly increased since 1980 (Koca and Metin, 2004). The fat in food carries much of its flavor and gives it a satisfying characteristic texture; removal of fat from cheese produces undesirable texture and appearance, altered rheological parameters, lack of flavor, poor keeping quality, and poor meltability and stretching property (Ustunol et al., 1995; Perry et al., 1997; Paulson et al., 1998; Rodríguez, 1998; Sipahioglu et al., 1999; Koca and Metin, 2004). Low-fat cheeses are characterized as having rubbery body and flavors that are atypical of corresponding full-fat varieties (Mistry, 2001); therefore, new ingredients and knowledge are needed (McKenna, 2003) to manufacture a product that is similar in flavor, melt, firmness, and texture to full-fat cheeses (Metzger and Mistry, 1995).

As the percentage of fat fraction is reduced, the proportions of protein and moisture fractions are increased. The protein-dominated microstructure of lowfat cheese (Sipahioglu et al., 1999) causes textural defects, such as rubberiness (Metzger and Mistry, 1995) and hardness. The bacterial population in curd is directly related to the fat content of cheese, and fat reduction leads to fewer starter cells than found in full-fat cheese (Laloy et al., 1996). Conversely, a high moisture content in low-fat cheese and lower salt concentration 
in the moisture fraction can enhance the activity and growth of microorganisms, including retained starters. Therefore, the peptide profile of low-fat cheese may become different from full-fat varieties (Ardö and Gripon, 1995).

Before they are renneted, the casein micelles in milk show no tendency to aggregate (Dalgleish, 1997). When milk is renneted, casein micelles aggregate (Walstra, 1999), providing a clear transition from a stable dispersion to a flocculated and gelled preparation (De Kruif, 1999). A large portion of the rennet is lost in the whey during cheese making (Gouda, 1987), depending on the $\mathrm{pH}$ at wheying (in the case of calf rennet, not microbial rennets) and the proportion of whey retained in the curd (Holmes et al., 1977; Lawrence et al., 1987; Fox, 1989). In general, only about $6 \%$ of the rennet added to cheese milk is retained in the curd (Fox, 1989); however, it is an important factor in the development of texture and flavor in the most aged cheese types because of its high proteolytic activity. Perhaps the main consequence of proteolysis is the conversion of the rubbery texture of initial curd to the smooth-bodied finished cheese (O'Keeffe et al., 1976). One may expect improvement of the textural and functional characteristics of low-fat cheese by the addition of higher rennet during cheese making, which leads to the higher retention of active rennet in the cheese curd (Holmes et al., 1977), and therefore, the higher rate of proteolysis. Ernstrom et al. (1958) reported for pasteurized- and rawmilk Cheddar cheese made with one-half the normal amount of rennet and Kindstedt et al. (1995) reported for low-moisture, part-skim Mozzarella made with 100, 80 , and $60 \%$ of normal usage of rennet, that rennet concentration significantly influenced the rate of proteolysis. However, no significant differences were detected in the flavor and body of Cheddar and the rheological characteristics and meltability of Mozzarella cheeses. Nevertheless, Dave et al. (2003) found that relative firmness (reported as the dynamic complex modulus) of full-, reduced-, and nonfat Mozzarella cheese was influenced by the level of rennet (0.25-, 1-, and 4-fold). In general, higher fat contents promoted more melting as did higher coagulant concentration. Cremoso Argentino soft cheeses without active rennet were hard and crumbly, but cheeses with a normal dose were soft and crumbly (Hynes et al., 2001).

Iranian white cheese is a brined cheese that is produced traditionally and industrially throughout Iran. Its characteristic flavor, body, and texture are developed at the ripening period of several weeks to months (Ehsani et al., 1999). The objective of the present study was to improve the textural, functional, and sensory properties of low-fat Iranian white cheese by increasing the rennet concentration 2- and 3-fold the normal usage.

\section{MATERIALS AND METHODS}

\section{Treatments, Cultures, and Rennet}

The 4 cheese treatments were as follows: control fullfat cheese (FFC), control low-fat cheese with normal concentration of rennet (LFC1C), low-fat cheese with double concentration of rennet (LFC2C), and low-fat cheese with triple concentration of rennet (LFC3C). Cheese batches manufactured using $50 \mathrm{~kg}$ of standardized milk for each treatment. Cheeses were manufactured in triplicate; each replicate was produced in $2 \mathrm{~d}$. Two lyophilized direct-to-vat mixed cultures (R-704 and FRC-60; Chr. Hansens Dairy Cultures, Denmark) were used as starter. Culture R-704 contained Lactococcus lactis subsp. cremoris and Lactococcus lactis subsp. lactis. Culture FRC-60 contained Lactococcus lactis subsp. cremoris, Lactococcus lactis subsp. lactic, Streptococcus thermophilus, and Lactobacillus delbrueckii subsp. bulgaricus. As a coagulant, chymosin, derived by fermentation [standard rennet; Chy-Max; Chr. Hansen Inc., Denmark; 183 international milk clotting units (IMCU)/mL (International Dairy Federation, 1997)], was used at 3 different concentrations: 4.5 IMCU of Chy-Max/kg of milk for FFC and LFC1C, 9.0 IMCU of Chy-Max/kg of milk for LFC2C, and 13.5 IMCU of ChyMax/kg of milk for LFC3C. Rennet was diluted 30-fold with cold water then added to each $50-\mathrm{kg}$ batch of milk.

\section{Cheese-Making Procedure}

Raw skim milk ( $<0.025 \%$ fat) was standardized with cream of determined fat content to $3.1 \%$ fat for FFC and to $0.6 \%$ fat for low-fat cheeses. Standardized milk was batch-pasteurized at $64^{\circ} \mathrm{C}$ for $30 \mathrm{~min}$ in a stainless steel vat placed in a water bath, cooled to $35^{\circ} \mathrm{C}$, and supplemented with $0.1 \mathrm{~g}$ of $\mathrm{CaCl}_{2} / \mathrm{kg}$ of milk. After inoculation of cultures, milk was held at $35^{\circ} \mathrm{C}$ for approximately $55 \mathrm{~min}$ for starter maturation before the addition of rennet. The curd was cut crossways in cubes of $2 \mathrm{~cm}^{3}$ when firm (approximately 55, 40, and $25 \mathrm{~min}$ for 1,2 , and $3 \times$ rennet concentrations, respectively). After being cut, the curd was allowed to settle for 3 to $5 \mathrm{~min}$ and then was gently agitated at a gradually increasing rate for $10 \mathrm{~min}$ to avoid fusion of freshly cut curd cubes and facilitate whey expulsion. This was followed by whey draining and wrapping the drained curd within a cheesecloth. Following this stage, the curd was pressed for $3 \mathrm{~h}$ (under a gradually increasing pressure up to approximately $2200 \mathrm{~Pa}$ at the first $1.5 \mathrm{~h}$ ) to complete draining. After pressing, the curd was cut in blocks $(4 \mathrm{~cm} \times 9 \mathrm{~cm} \times 9 \mathrm{~cm})$. The blocks were stored at 
23 to $25^{\circ} \mathrm{C}$ for 19 to $20 \mathrm{~h}$, placed in 1.5 -L airtight plastic containers, and covered with $13 \%$ brine (brine was pasteurized beforehand at $80^{\circ} \mathrm{C}$ for $10 \mathrm{~min}$, filtered through a clean cloth after rapid cooling, and $\mathrm{pH}$-adjusted to 4.65 by the addition of $99 \%$ lactic acid). After sealing, the containers were stored first at 23 to $25^{\circ} \mathrm{C}$ for $48 \mathrm{~h}$ and then refrigerated at 5 to $6^{\circ} \mathrm{C}$ for the ripening period of $9 \mathrm{wk}$.

\section{Chemical Analysis}

Titrable acidity of milk and whey was determined by the Dohrnic method. The $\mathrm{pH}$ of milk, whey, and cheese samples was measured using a WTW digital $\mathrm{pH}$ meter (model pH 525; Germany). Cheese was analyzed for moisture content by vacuum-oven (AOAC, 1997; method number 926.08) and for ash content by the dry ash method (AOAC, 1997; method number 935.42). The fat content of milk, cream, and cheese was determined by the Gerber method. Total protein contents of milk and cheese samples were determined by measuring total nitrogen using the Kjeldahl method (AOAC, 1997; method number 920.123) and converting it to protein content by multiplying by 6.38 . Whey and milk TS were determined by drying 8 to $11 \mathrm{~g}$ of milk or whey at $100^{\circ} \mathrm{C}$ for $4 \mathrm{~h}$. As an index of development of proteolysis, soluble nitrogen in $12 \%$ TCA was determined (Green, 1977) as described by Katsiari et al. (2000). The soluble nitrogen in $12 \%$ TCA was expressed as a percentage of total nitrogen. Calcium content of cheese samples was determined using atomic absorption spectroscopy (Shimadzu UV-670 A, Japan). Viscosities of whey samples were determined using a rotational viscometer (Fungilab B. A., Visco Elite model; Spain) at $23^{\circ} \mathrm{C}$. All chemical measurements were done in triplicate or more. Cheese samples were chemically analyzed at the ninth week of ripening. Whey samples were collected during whey draining.

\section{Cheese Yield, Fat, and Protein Recovery}

Yield was calculated as the weight of cheese before brining (after 19 to $20 \mathrm{~h}$ of storage at 23 to $25^{\circ} \mathrm{C}$ ) divided by the weight of the milk used. The percentage of fat or protein recovered in the cheese was the total amount of fat or protein in the cheese divided by the total amount of fat or protein in the milk (Johnson et al., 2001).

\section{Meltability}

The meltability of cheese was measured as follows. Grated cheese plugs weighing approximately $3 \mathrm{~g}$ were placed into test tubes. The test tubes were covered with aluminum foil, and holes were made to let the hot gas escape during heating (Koca and Metin, 2004). The test tubes were placed vertically in a refrigerator at $5{ }^{\circ} \mathrm{C}$ for $30 \mathrm{~min}$ and then horizontally in an oven and heated at $100^{\circ} \mathrm{C}$ for $90 \mathrm{~min}$. Meltability was measured in millimeters from the bottom of the test tube to the point at which the cheese had stopped flowing (Poduval and Mistry, 1999). Meltability of cheese samples was determined at the ninth week of ripening.

\section{Microstructure}

Cheese samples were prepared for SEM at the ninth week of ripening following the method of Drake et al. (1996) with modifications. Cheese blocks were cut into approximately 5 to $6 \mathrm{~mm}^{3}$ cubes with a sharp razor and immersed in $2.5 \%$ gluteraldehyde fixative (E. Merck Science, Germany) for $3 \mathrm{~h}$. Cubes were then washed in 6 changes of distilled water ( 1 min each time), dehydrated in a graded $(40,55,70,85,90$, and $96 \%)$ series of ethanol for 30 min each followed by defatting in 3 changes in chloroform (10 min each time). The defatted samples were kept refrigerated and covered with ethanol until they were freeze-fractured in liquid nitrogen (Sipahioglu et al., 1999) to approximately 1-mm pieces. These pieces were mounted on aluminum stubs by silver paint, dried to critical point, and coated with gold for $6 \mathrm{~min}$ in a sputter-coater (Balzers, type SCD 005; Baltec Inc., Switzerland). Samples were viewed in a SEM (XL Series, model XL30; Philips, The Netherlands) operated at $15.0 \mathrm{kV}$. Photomicrographs were recorded at 5000, 7000, and 9000 magnifications.

\section{Rheological Analysis}

Uniaxial compression. The simplest fundamental test, uniaxial compression (Tunick, 2000) was performed using a HTE Universal Testing Machine (SSeries Bench U.T.M. Model H5K-S; Hounsfield Test Equipment Ltd., UK) with a 500-N load cell. A flat plunger with $49 \mathrm{~mm}$ diameter was attached to the moving crosshead. Cheese blocks were cut into $15-\mathrm{mm}^{3}$ cubes at $6^{\circ} \mathrm{C}$. Samples were taken from at least $2 \mathrm{~cm}$ deep in cheese blocks (Romeih et al., 2002) and immediately placed in airtight containers to prevent dehydration. Samples were equilibrated to room temperature for at least $4 \mathrm{~h}$ prior to testing. Samples were compressed uniaxially at a crosshead speed of $50 \mathrm{~mm} / \mathrm{min}$ with $57 \%$ deformation $(8.5 \mathrm{~mm})$ from the initial height of the sample in one bite. The fracture stress $\left(\sigma_{f}\right)$ was measured as the force divided by the initial cross-sectional area of the sample (Sipahioglu et al., 1999). The Hencky strain $\left(\varepsilon_{h}\right)$ was calculated as $\ln h_{0} /\left(h_{0}-\Delta h_{f}\right)$, where $h_{0}$ is the original height and $\Delta \mathrm{h}_{f}$ is the change 
in the height (Hort and Grys, 2001) at the point of fracture. The modulus of elasticity was calculated as the secant modulus (Mohsenin, 1986) using engineering strain at one-half of the fracture stress and work performed up to fracture calculated from the area under the curve (Tunick, 2000). Each cheese was analyzed in triplicate.

Dynamic rheological measurements. Small amplitude oscillatory shear measurements were performed with a UDS 200 rheometer (Universal Dynamic Spectrometer; Paar Physica Inc., Germany). The measuring geometry consisted of 2 parallel plates with a diameter of $25 \mathrm{~mm}$ and 1-mm gap size (sample thickness). Excessive cheese was trimmed carefully with a razor blade, and the sample was allowed to rest for 20 min on the rheometer to allow the stresses induced during sample handling to relax. The linear viscoelastic range was determined by performing a strain sweep. Frequency, set at $0.1 \mathrm{~Hz}$, as the percentage of strain values varied from 0.01 to $2 \%$, resulting in a strain sweep. A strain in the linear region (0.02) was then selected, and a frequency sweep was performed. Mathematical models that describe relationships between structural parameters and deformation outside the linear range have not been well developed (Ustunol et al., 1995). The parameter calculated was $\mathbf{G}^{\prime}$, the storage modulus that is a measure of elastic nature (Steffe, 1996). Strain was set at $0.02 \%$ as the frequency varying from 0.1 to $10 \mathrm{~Hz}$, resulting in a frequency sweep. Samples were cut at least $1 \mathrm{~cm}$ deep of the cheese blocks at $6^{\circ} \mathrm{C}$. These samples were immediately placed in small airtight plastic containers and equilibrated at room temperature $\left(20 \pm 1^{\circ} \mathrm{C}\right)$ for at least $4 \mathrm{~h}$. Values are the averages of 2 measurements for 3 replicates of each cheese. All rheological measurements were performed at the ninth week of ripening.

\section{Sensory Evaluation}

An acceptance sensory panel evaluated randomly coded cheese samples. Acceptance (consumer) panel consisted of 78 members, 36 were female and 42 male, and age ranged from 23 to $33 \mathrm{yr}$. Consumer panelists were the students of faculties of Agricultural Engineering and Natural Resources of Tehran University and the employees of research and development ( $R$ \& D) bureau of Pak Dairy Company. Prior to testing, panelists were requested to complete the questionnaire asking gender, age, and frequency of cheese consumption (do not eat cheese, $<1 / \mathrm{mo}, 2$ to 4 times/mo, 5 to 6 times/ mo, and $>6$ times $/ \mathrm{mo})$. Panelists $(\mathrm{n}=2)$ who consumed cheese 2 to 4 times/mo or less were eliminated from data analysis. The FFC, LFC1C, LFC2C, and LFC3C were evaluated for texture, flavor, appearance, and overall acceptability by the consumer panel on a 5 -point hedonic scale $(1=$ least liked to $5=$ most liked). Cheese blocks were cut into standard, bite-sized pieces; each piece measured $1.3 \times 0.9 \times 0.9 \mathrm{~cm}$ (Chen et al., 1979). Cheese pieces were placed into airtight plastic containers and conditioned at room temperature for $2 \mathrm{~h}$ before evaluation. Crackers and water were offered without limit to panelists during testing for cleaning the palates.

\section{Statistical Analyses}

The experiment was replicated 3 times in a completely randomized design. The ANOVA was carried out using PROC GLM of SAS (Version 8.2, SAS Inst., Inc., Cary, NC) to determine the differences between data means at $5 \%$ significant level.

\section{RESULTS AND DISCUSSON}

\section{Composition of Milk}

Total physicochemical characteristics of the milk used for cheese manufacture are shown in Table 1 . In agreement with the literature (Ustunol et al., 1995; Rudan et al., 1999; Kahyaoglu and Kaya, 2003), as the fat content was decreased, the moisture and protein contents of the milks increased significantly. There was no statistical difference in the calculated milk SNF content and $\mathrm{pH}$ value of milks, and, as expected, full-fat milk with a lower moisture content (higher TS) had significantly higher viscosity than low-fat milks.

\section{Composition of Cheese, Cheese Yield, Protein, and Fat Recovery}

In agreement with the literature (Bryant et al., 1995; McMahon et al., 1999; Rudan et al., 1999; Sipahioglu et al., 1999; Romeih et al., 2002; Dave et al., 2003; Kahyaoglu and Kaya, 2003), low-fat cheeses contained a significantly higher protein and moisture contents than FFC (Table 2). Decreasing the fat content also led to a significant decrease in the level of moisture in nonfat substance (MNFS) and, subsequently to the ratio of moisture to protein (M:P), which was in agreement with the reports of other researchers (Rudan et al., 1999; Romeih et al., 2002; Dave et al., 2003; Kahyaoglu and Kaya, 2003). Fat and moisture act as the filler in the casein matrix of cheese texture. When the fat content was decreased, the moisture did not replace the fat on an equal basis (Rudan et al., 1999), so the total filler volume was decreased, resulting in lower MNFS and M:P. As the rennet concentration increased, the percentage of protein fraction significantly increased, and M:P decreased. Doubling the rennet concentration 
Table 1. Mean $( \pm \mathrm{SD})$ of physicochemical characteristics of milks.

\begin{tabular}{lrrrr}
\hline & \multicolumn{1}{c}{ FFC } & \multicolumn{1}{c}{ LFC1C } & \multicolumn{1}{c}{ LFC2C } & \multicolumn{1}{c}{ LFC3C } \\
\hline Fat, \% & $3.14^{\mathrm{a}} \pm 0.12$ & $0.62^{\mathrm{b}} \pm 0.11$ & $0.61^{\mathrm{b}} \pm 0.13$ & $0.63^{\mathrm{b}} \pm 0.17$ \\
pH & $6.59^{\mathrm{a}} \pm 0.01$ & $6.57^{\mathrm{a}} \pm 0.01$ & $6.58^{\mathrm{a}} \pm 0.02$ & $6.59^{\mathrm{a}} \pm 0.01$ \\
Acidity & $15^{\mathrm{a}} \pm 0.16$ & $15^{\mathrm{a}} \pm 0.19$ & $15^{\mathrm{a}} \pm 0.15$ & $15^{\mathrm{a}} \pm 0.16$ \\
Moisture, \% & $88.70^{\mathrm{b}} \pm 0.41$ & $91.08^{\mathrm{a}} \pm 0.17$ & $91.05^{\mathrm{a}} \pm 0.21$ & $91.06^{\mathrm{a}} \pm 0.34$ \\
Milk SNF, \% & $8.27^{\mathrm{a}} \pm 0.07$ & $8.26^{\mathrm{a}} \pm 0.05$ & $8.28^{\mathrm{a}} \pm 0.06$ & $8.27^{\mathrm{a}} \pm 0.04$ \\
Protein, \% & $3.05^{\mathrm{b}} \pm 0.01$ & $3.12^{\mathrm{a}} \pm 0.01$ & $3.12^{\mathrm{a}} \pm 0.01$ & $3.11^{\mathrm{a}} \pm 0.01$ \\
Viscosity, cp & $3.50^{\mathrm{a}} \pm 0.03$ & $3.40^{\mathrm{b}} \pm 0.01$ & $3.41^{\mathrm{b}} \pm 0.01$ & $3.41^{\mathrm{b}} \pm 0.02$ \\
\hline
\end{tabular}

\footnotetext{
${ }^{\mathrm{a}, \mathrm{b}}$ Means within the same row with different superscripts differ $(P<0.05)$.

${ }^{1} \mathrm{FFC}=$ Control, full-fat cheese; LFC1C = control, low-fat cheese with normal concentration of rennet; LFC2C = low-fat cheese with double concentration of rennet; and LFC3C = low-fat cheese with triple concentration of rennet.
}

significantly increased the moisture content and increased the percentage of fat in DM and MNFS, which was likely the result of higher protein content in LFC2C. However, increasing the rennet concentration 3 -fold the normal usage, although it appeared to increase the protein content more, significantly reduced the moisture content, fat in DM, and MNFS in comparison with LFC2C because of more syneresis.

Considering the higher protein content of LFC3C, the lower degree of protein hydration was probably due to further and more compact interactions between proteins. Fat reduction from 23 to $6 \%$ and an increase in the rennet concentration significantly increased the $\mathrm{pH}$ of the product. A higher $\mathrm{pH}$ value is probably due to enhanced proteolysis, which was indicated by higher soluble nitrogen in 12\% TCA in control low-fat cheese and treatments with higher rennet concentration. De- creasing the fat content led to an increase in the percentage of ash in LFC1C. Fife et al. (1996) reported similar ash contents for part-skim and low-fat Mozzarella cheeses. McMahon et al. (1999) found that reduced-fat Mozzarella cheese had significantly higher ash content than the low-fat variety, which confirmed the results obtained in this work. The increase in the ash content was probably a result of increased protein content, which would increase protein-bound minerals, such as colloidal calcium phosphate, and increased moisture (replacing fat) content, resulting in an increase in the total amount of soluble minerals, such as ionic $\mathrm{Ca}, \mathrm{Na}$, and $\mathrm{K}$ (Fife et al., 1996; McMahon et al., 1999). Doubling the rennet concentration increased the ash content, probably because of increased protein and moisture contents, but increasing the rennet concentration 3 -fold the normal dose decreased the ash content

Table 2. Mean $( \pm \mathrm{SD})$ of chemical composition, cheese-making yield, protein, and fat recoveries of full-fat and low-fat cheeses made with different concentrations of rennet. ${ }^{1}$

\begin{tabular}{|c|c|c|c|c|}
\hline & FFC & LFC1C & LFC2C & LFC3C \\
\hline Fat, \% & $23.07^{a} \pm 0.09$ & $6.07^{\mathrm{b}} \pm 0.11$ & $6.09^{b} \pm 0.10$ & $6.04^{b} \pm 0.11$ \\
\hline $\mathrm{pH}$ & $4.84^{\mathrm{d}} \pm 0.02$ & $4.87^{\mathrm{c}} \pm 0.02$ & $4.95^{\mathrm{b}} \pm 0.03$ & $4.99^{\mathrm{a}} \pm 0.02$ \\
\hline Moisture, \% & $54.79^{\mathrm{d}} \pm 0.72$ & $63.21^{\mathrm{b}} \pm 0.41$ & $64.47^{\mathrm{a}} \pm 0.67$ & $62.66^{\mathrm{c}} \pm 0.39$ \\
\hline $\mathrm{FDM}^{2} \%$ & $50.87^{a} \pm 1.1$ & $16.30^{c} \pm 0.98$ & $16.89^{\mathrm{b}} \pm 1.3$ & $16.07^{\mathrm{c}} \pm 1.1$ \\
\hline Protein, $\%$ & $17.79^{\mathrm{d}} \pm 0.23$ & $21.26^{\mathrm{c}} \pm 0.25$ & $22.15^{\mathrm{b}} \pm 0.18$ & $24.56^{\mathrm{a}} \pm 0.34$ \\
\hline $\mathrm{M}: \mathrm{P}^{3}$ & $3.08^{\mathrm{a}}$ & $2.97^{\mathrm{b}}$ & $2.91^{\mathrm{c}}$ & $2.55^{\mathrm{d}}$ \\
\hline MNFS, ${ }^{4} \%$ & $71.25^{\mathrm{a}} \pm 0.27$ & $67.20^{\mathrm{c}} \pm 0.22$ & $68.58^{b} \pm 0.43$ & $66.59^{c} \pm 0.34$ \\
\hline Ash, \% & $4.57^{\mathrm{d}} \pm 0.03$ & $5.86^{\mathrm{c}} \pm 0.02$ & $5.95^{\mathrm{a}} \pm 0.02$ & $5.91^{\mathrm{b}} \pm 0.01$ \\
\hline $\mathrm{Ca}, \%$ & $0.35^{\mathrm{d}} \pm 0.02$ & $0.42^{\mathrm{c}} \pm 0.04$ & $0.52^{\mathrm{b}} \pm 0.06$ & $0.69^{a} \pm 0.04$ \\
\hline $\mathrm{Ca}, \%$ of protein & $1.96^{\mathrm{c}} \pm 0.06$ & $1.96^{\mathrm{c}} \pm 0.07$ & $2.35^{\mathrm{b}} \pm 0.09$ & $2.82^{\mathrm{a}} \pm 0.06$ \\
\hline TCA-SN, ${ }^{5} \%$ TN & $0.25^{\mathrm{d}} \pm 0.05$ & $3.74^{\mathrm{c}} \pm 0.17$ & $4.23^{\mathrm{b}} \pm 0.09$ & $5.63^{\mathrm{a}} \pm 0.22$ \\
\hline Yield, \% & $12.2^{\mathrm{a}} \pm 0.2$ & $9.9^{\mathrm{b}} \pm 0.2$ & $8.6^{\mathrm{c}} \pm 0.4$ & $8.4^{\mathrm{d}} \pm 0.3$ \\
\hline Fat recovery, \% & $90.5^{\mathrm{b}} \pm 1.4$ & $99^{\mathrm{a}} \pm 1.2$ & $86^{\mathrm{c}} \pm 0.9$ & $84^{\mathrm{d}} \pm 1.3$ \\
\hline Protein recovery, \% & $71.16^{\mathrm{a}} \pm 0.9$ & $67.46^{\mathrm{b}} \pm 0.8$ & $61.05^{\mathrm{d}} \pm 1.4$ & $66.12^{\mathrm{c}} \pm 1.3$ \\
\hline
\end{tabular}

a,b,c,d Means within the same row with different superscripts differ $(P<0.05)$.

${ }^{1} \mathrm{FFC}=$ Control, full-fat cheese; LFC1C = control, low-fat cheese with normal concentration of rennet; LFC2C = low-fat cheese with double concentration of rennet; and LFC3C = low-fat cheese with triple concentration of rennet.

${ }^{2} \mathrm{FDM}=$ Fat in DM.

${ }^{3} \mathrm{M}: \mathrm{P}=$ Ratio of moisture to protein, calculated using the means of moisture and protein.

${ }^{4}$ MNFS $=$ Moisture in nonfat substance.

${ }^{5} \mathrm{TCA}-\mathrm{SN}=12 \%$ TCA Soluble nitrogen, expressed as a percentage of total nitrogen (TN). 
in comparison with LFC2C. This was probably because of lower moisture content in LFC3C. Calcium content was significantly increased with decreasing fat content, in agreement with the other researchers (Rudan et al., 1999; Dave et al., 2003). It is important to consider calcium content when studying cheese proteolysis and functionality (Dave et al., 2003). Calcium concentration is an index of acid production up to the draining stage (Lawrence et al., 1984), and it is probable to find a relationship among the total calcium content of the cheese, the amount of residual chymosin, the plasmin retained in the cheese, and the casein breakdown during ripening (Lawrence et al., 1984, 1987). However, when comparing cheeses with differing fat content, it is better to measure calcium content in relation to protein content (Dave et al., 2003). Calcium contents of FFC and LFC1C, as the functions of protein contents, were not different, which was confirmed by the reports of Dave et al. (2003) and Rudan et al. (1999) for Mozzarella cheeses with different fat contents. Therefore, the observed differences in functionality and rheological characteristics between these 2 treatments cannot be attributed to differences in calcium contents. Increasing the rennet concentration in $\mathrm{LFC} 2 \mathrm{C}$ and $\mathrm{LFC} 3 \mathrm{C}$ led to increased calcium contents. Because of the increased moisture fraction of low-fat cheeses, which contain soluble chymosin (Rudan et al., 1999) that can likely enhance the activity and growth of microorganisms (Mistry, 2001), 12\% TCA soluble nitrogen increased in the low-fat control in comparison with the full-fat control cheese, reflecting a higher rate of proteolysis. This finding is in agreement with the results of Romeih et al. (2002). As expected (Spangler et al., 1991; Wium et al., 1998), LFC2C and LFC3C had higher soluble nitrogen content. The cheese-making yield significantly decreased as the fat content in the cheese decreased. Milk fat, one of the major components in milk, is trapped in the casein matrix during cheese making (Rudan et al., 1999). Although it is true that fat in cheese is replaced by moisture (Mistry, 2001), an overall reduction in yield ( $\mathrm{kg}$ of cheese/kg of milk) is inevitable in the production of cheese from low-fat milk (Romeih et al., 2002) because the total amount of fat removed is not equal the amount of moisture added (Mistry, 2001); therefore, the sum of the casein and fat contents of the milk, which are the principal components determining cheese yield, are reduced (Romeih et al., 2002). Fat and protein recoveries in the cheese were also significantly affected by the fat content. Rudan et al. (1999) reported that fat content significantly affected the percentage of fat recovery, but not the percentage of nitrogen recovery, in Mozzarella cheese and whey. In the present study, as the target fat content in the cheese decreased from 23 to $6 \%$, fat recovery significantly increased, while protein recovery decreased. Increasing the rennet concentration decreased the fat recovery. The greater the rennet concentration, the lower the fat recovery, but the protein recovery had a different path (i.e., doubling the rennet concentration caused a decrease in the protein recovery similar to the fat recovery, but increasing the rennet concentration 3-fold the normal dose increased it). Considering that fat and protein recoveries are important in cheese yield (Mistry, 2001) and excessive proteolysis diminishes the yield of cheese and retention of fat by the curd (Green, 1977), increasing the rennet concentration decreased the cheese yield. Although the protein recovery significantly increased when the rennet concentration increased from 2 - to 3 -fold, a significant decrease in the fat recovery may have lowered the cheese yield for LFC3C. Viscosity mean values of 3.38 and $3.39 \mathrm{cp}$ for whey samples of FFC and LFC1C, respectively, showed that the fat reduction had no affect on whey viscosity; however, increasing the rennet concentration increased the whey viscosity to $3.64 \mathrm{cp}$ for LFC2C and to $3.58 \mathrm{cp}$ for LFC3C. Similar whey viscosities for FFC and LFC1C showed that increased fat recovery in low-fat control cheese substituted the decreased protein recovery. Increased whey viscosity of treatments with higher rennet concentration appeared to have a relationship with protein and fat recoveries. A higher percentage of protein recovery in LFC3C led to the lower whey viscosity that also lowered the amount of TS (6.22\%) in comparison with LFC2C (6.40\%).

\section{Meltability}

Meltability is one of the properties of cheese at elevated temperatures (Kahyaoglu and Kaya, 2003) and measures the ability of cheese particles to flow or spread upon heating (Fife et al., 1996; Muthukumarappan et al., 1999). The meltability of the treatments were $68 \pm$ $4.5,55 \pm 1.4,58 \pm 2.0$, and $45 \pm 3.5 \mathrm{~mm}$ for FFC, LFC1C, LFC2C, and LFC3C, respectively. The full-fat control cheese melted to a greater extent than did the low-fat cheeses. Decreasing the fat content resulted in lower M:P, less protein hydration, and a higher level of interactions between proteins (McMahon et al., 1999; Kahyaoglu and Kaya, 2003), which decreased the protein flow when heated. Doubling the rennet concentration significantly increased the meltability, probably because of further breakdown of the proteins to smaller peptide and amino acids (Dave et al., 2003) and solubilization of resulting fragments (Tunick et al., 1993), which is monitored by the higher level of $12 \%$ TCA soluble nitrogen at LFC2C in comparison with LFC1C. Higher breakdown of proteins caused the cheese to become softer and melt more easily because the energy required for the protein matrix to move lessened (Dave 
et al., 2003). Although LFC3C had the highest $12 \%$ TCA soluble nitrogen content, its degree of meltability was significantly lower, probably because of the more compact structure of the cheese and less freedom of movement for the proteins. Kindstedt et al. (1995) found no significant effect of coagulant concentration on meltability of low-moisture, part-skim Mozzarella cheese. The narrow range of coagulant concentration variation (100, 80, and $60 \%$ normal usage) may be the reason for this phenomenon. In similarity to our results, Dave et al. (2003) found an increase in the meltability as the rennet concentration increased 2- and 4-fold for nonfat, reduced-fat (10\% target fat), and control (19\% target fat) Mozzarella cheeses.

\section{Microstructure}

Differences between cheeses could be visually observed in images obtained by SEM (Figures 1 and 2). Every cheese variety has its characteristic structural features that reflect the chemical and biological changes in the cheese (Abd El-salam and El-shibiny, 1973). In the SEM micrographs of FFC, the protein matrix was open with spaces occupied by the fat globules. Microstructure of the low-fat cheeses was clearly different from FFC, so that the number of milk fat globules decreased, and the protein matrix became more compact. This probably explained the hard texture observed with the low-fat cheeses even though they were significantly higher in moisture content (Bryant et al., 1995). Protein-dominated microstructure of LFC1C was undisturbed, reflecting the extensive elastic character of the cheese. Micrographs of LFC2C had more fusions and folds, reflecting the higher proteolysis that occurred during storage. The higher rate of protein breakdown may explain the softer texture observed in LFC2C when compared with LFC1C. Tripling the rennet concentration resulted in a coarser and more compact protein network (Figure 2). Subsequent rheological measurements showed that LFC3C had a higher elastic modulus and stress at fracture than LFC2C and even than LFC1C, proposing that the coarsening of the network and the growth of the hardness parameters are parallel events (Wium and Qvist, 1998).

\section{Rheological Analysis}

Uniaxial compression. The uniaxial compression parameters of treatments are shown in Table 3. The LFC1C showed a significantly higher stress at fracture, work performed up to fracture (toughness), and Young's modulus of elasticity in comparison with FFC. Madsen and Ardö (2001) also reported that the Danbo cheeses with $>20 \%$ fat in DM had significantly higher stress at
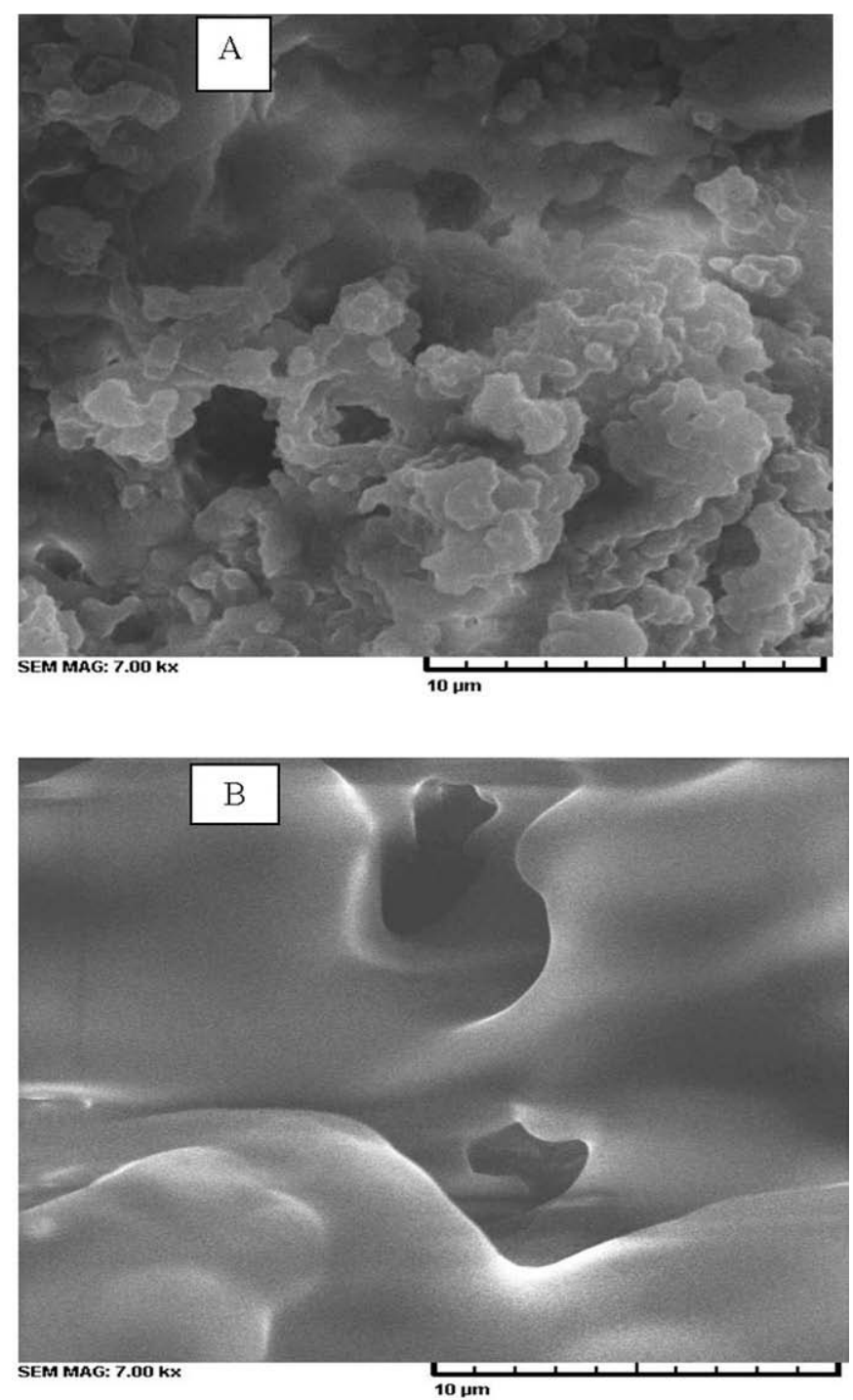

Figure 1. The SEM micrographs of Iranian white cheese: full-fat cheese with normal concentration of rennet (A); low-fat cheese with normal concentration of rennet (B).

fracture, work up to fracture, and deformability modulus than the cheeses with $>30$ and $>45 \%$ fat in DM. In contrast to their results, we found that the firmer cheese (LFC1C) was shorter (had lower Hencky strain at fracture) than the softer cheese (FFC). Wium et al. (2003) similarly reported that the firmer UF-Feta cheese was also shorter. The value of Hencky strain at fracture decreased with increasing rennet concentration in agreement with Wium and Qvist (1998) and Wium et al. (1998) because of the higher number of hydrolyzed bonds. The higher the rennet concentration, the lower the Hencky strain at fracture point. In agreement with the storage modulus obtained from oscillatory measurements, doubling the rennet concentration significantly 

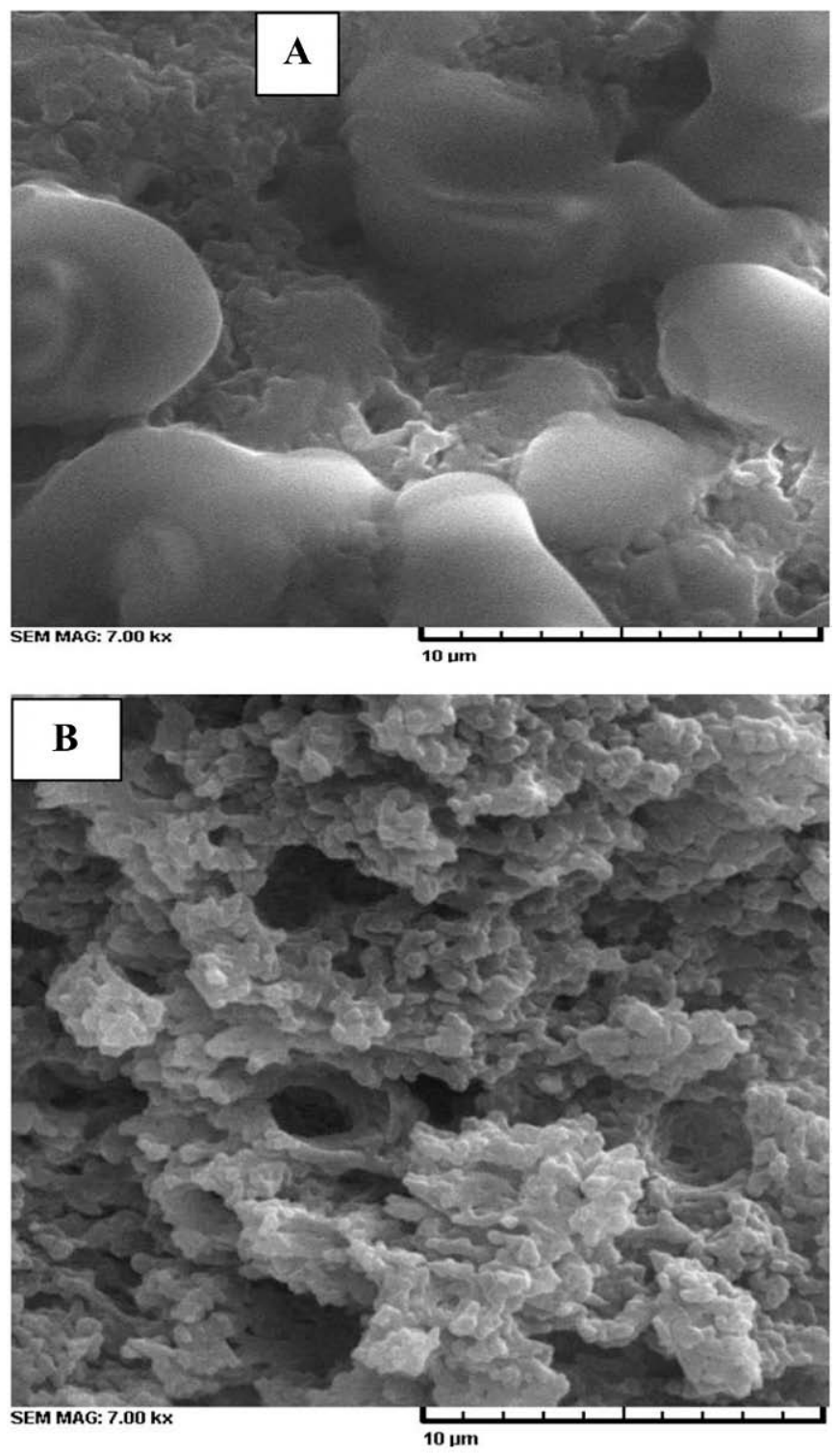

Figure 2. The SEM micrographs of Iranian white cheese: low-fat cheese with double concentration of rennet (A); low-fat cheese with triple concentration of rennet (B).

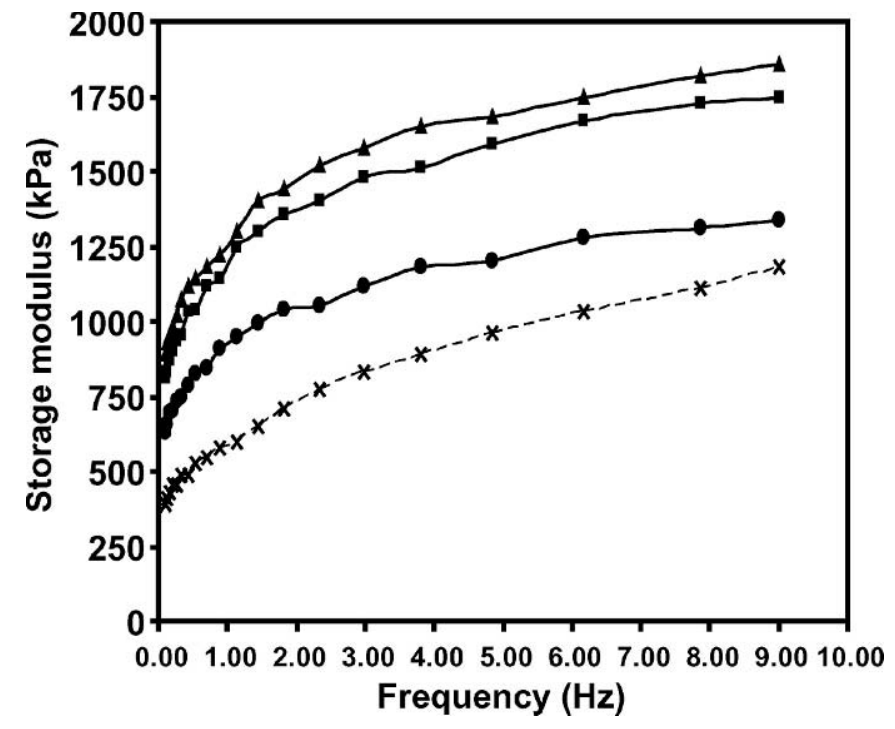

Figure 3. Storage moduli of Iranian white cheese: full-fat cheese with normal concentration of rennet $(*)$, low-fat cheese with normal concentration of rennet ( $\mathbf{\square})$, low-fat cheese with 2 -fold concentration of rennet (-), and low-fat cheese with 3-fold concentration of rennet $(\mathbf{\Delta})$.

lowered the stress at fracture, work performed up to fracture, and Young's modulus of the product; increasing the rennet concentration to 3 -fold the normal usage increased these parameters even slightly higher than those of LFC1C.

Dynamic rheological measurements. Frequency sweep tests were used to determine whether the fat reduction and increasing the rennet concentration influences the textural characteristics of the cheese. The comparison of $\mathrm{G}^{\prime}$ of treatments is seen in Figure 3. Both storage and loss moduli (results not shown) of all treatments were dependent on frequency and demonstrated similar shapes and trends. The $\mathrm{G}^{\prime}$ was greater than $G^{\prime \prime}$ at any frequency for all treatments, which indicates a dominant contribution of the elastic component to the viscoelasticity (Kayaoglu and Kaya, 2003), reflecting the typical behavior for a solid viscoelastic material (Ustunol et al., 1995). Both storage and loss moduli of 4 cheeses were dependent on frequency ( $\mathrm{Ma}$

Table 3. Mean $( \pm \mathrm{SD})$ of uniaxial compression parameters of FFC, LFC1C, LFC2C, and LFC3C. ${ }^{1}$

\begin{tabular}{lccrr}
\hline & FFC & LFC1C & LFC2C & \multicolumn{1}{c}{ LFC3C } \\
\hline Stress at fracture, $\mathrm{kPa}$ & $80^{\mathrm{d}} \pm 26.1$ & $157^{\mathrm{b}} \pm 30.7$ & $90^{\mathrm{c}} \pm 27.4$ & $161^{\mathrm{a}} \pm 34.1$ \\
Strain at fracture & $0.32^{\mathrm{a}} \pm 0.03$ & $0.26^{\mathrm{b}} \pm 0.01$ & $0.20^{\mathrm{c}} \pm 0.03$ & $0.19^{\mathrm{d}} \pm 0.05$ \\
Work, kJm & $8^{\mathrm{d}} \pm 3.2$ & $24^{\mathrm{b}} \pm 9.1$ & $14^{\mathrm{c}} \pm 7.4$ & $32^{\mathrm{a}} \pm 8.4$ \\
Young's modulus, $\mathrm{kPa}$ & $730^{\mathrm{d}} \pm 68.7$ & $1060^{\mathrm{b}} \pm 51.6$ & $847^{\mathrm{c}} \pm 61.6$ & $1173^{\mathrm{a}} \pm 41.8$ \\
\hline
\end{tabular}

a,b,c,d Means within the same row with different superscripts differ $(P<0.05)$.

${ }^{1} \mathrm{FFC}=$ Control, full-fat cheese; LFC1C = control, low-fat cheese with normal concentration of rennet; LFC2C = low-fat cheese with double concentration of rennet; and LFC3C = low-fat cheese with triple concentration of rennet. 
et al., 1996), reflecting relaxation of more bonds when the timescale of the applied stress is longer (Lucey, 2002). Reduction of fat content from $23 \%$ in FFC to $6 \%$ in LFC1C significantly increased the values of $\mathrm{G}^{\prime}$ probably because of the increased proportion of protein fraction. However, the value of $\tan \delta$ was lower for LFC1C (results not shown), probably because of decreased volume fraction of filler (fat and moisture), which is responsible for the viscous properties of cheese (Kayaoglu and Kaya, 2003). Decreasing the MNFS and M:P of LFC1C caused the product to become more solidlike even though its loss modulus was higher than FFC. Although the results obtained in the present study were not similar to those found by $\mathrm{Ma}$ et al. (1996), who reported that full-fat Cheddar cheeses had more solidlike structure, similar results have been reported frequently by other researchers (Dave et al., 2003; Kayaoglu and Kaya, 2003). Doubling the rennet concentration decreased the value of $\mathrm{G}^{\prime}$ probably because of increased proteolysis, and caused the LFC2C to become less elastic than LFC1C. Increasing the rennet concentration to 3 times the normal usage significantly increased the value of $\mathrm{G}^{\prime}$ in comparison with twice the concentration, even somewhat to that of LFC1C.

Similar to the results obtained for LFC3C, Wium and Qvist (1998) and Wium et al. (1998, 2003) reported that Feta cheeses and 2-d-old fat-free Feta cheeses (made from ultrafiltered milk using direct acidification) with a higher rennet concentration (and, therefore, a higher level of soluble nitrogen) had a coarser protein network structure and were firmer than cheeses with less rennet. On the contrary, Spangler et al. (1991) found that in the manufacturing of Gouda from ultrafiltered milk, cheeses with rennet concentration at one-third of conventional cheese had significantly increased texture profile analysis hardness relative to those with a level of two-thirds of conventional cheese at 4 and 25 wk. According to those researchers, this result was most likely due to increased proteolysis in cheeses with higher rennet concentration. Breakdown products of casein are water-soluble and cannot contribute to the framework provided by the protein matrix; therefore, the cheese becomes softer (Ustunol et al., 1995). Similar events could probably be the reason of the softer texture observed in LFC2C in comparison with LFC1C. Effective aggregation of casein micelles cannot take place until a minimum of 60 to $70 \%$ of $\kappa$-casein has been hydrolyzed (Guinee and Law, 2002). The higher concentration of rennet increases the rate of $\kappa$-casein hydrolysis (Lomholt and Qvist, 1997); therefore, this minimum value is reached sooner, leading to a quicker initiation of aggregation at a higher rate (Green et al., 1978; Wium et al., 1998) because of less repulsive forces (Wium et al., 2003) and an increased number of aggre- gating micelles at unit time. The higher rate of aggregation may affect the initial mode of aggregation of casein particles, leading to a denser network structure and a firmer texture (Wium and Qvist, 1998). In addition, after a gel has been formed, collisions between casein micelle aggregates and network strands lead to a further aggregation (Lomholt and Qvist, 1997) and coarsening of the network. This process likely progressively strengthens the links between micelles (Green et al., 1978) and increases the rheological moduli (Lomholt and Qvist, 1997). It appears that the rate of gel firming or network coarsening caused by rearrangement is increased as the concentration of rennet is increased (Lomholt and Qvist, 1997; Wium and Qvist, 1998). It is proposed that rennet has 2 opposing effects on the texture of cheese. First, it causes the texture of cheese to become softer during ripening through proteolysis and breakdown of protein matrix, which is dominant at the normal or slightly higher dosage, but also, higher rennet concentrations (depending upon the type of the cheese and manufacturing procedure) leads to more compact aggregation of casein micelles during gel formation and extensive rearrangement of the bonds at the formed gel. Under such conditions, even the higher rate of proteolysis during cheese storage cannot negate the firmness, and microstructure of the product would remain coarse unless a very high concentration of rennet is used or a long period of ripening is applied until the softening effect of proteolysis becomes dominant and tends to make the cheese softer (Wium et al., 1998).

\section{Sensory Evaluation}

Table 4 shows the results of the taste panelists (Foegeding et al., 2003). As expected, FFC received the highest scores for all attributes. Fat content reduction significantly affected Iranian white cheese texture, appearance, flavor, and overall acceptability. Sipahioglu et al. (1999) also reported that reduced- and low-fat Feta cheeses received lower flavor and texture scores than full-fat cheeses. Cheeses with lower fat usually have less pronounced flavor than full-fat products, possibly as a result of flavor dilution in reduced- and lowfat cheese because of excessive moisture retention (Sipahioglu et al., 1999). Although the cheeses with double rennet concentration received higher scores for texture and overall acceptability than the 2 other low-fat cheeses, their flavor and appearance had no significant difference from $\mathrm{LFC} 1 \mathrm{C}$ and $\mathrm{LFC} 3 \mathrm{C}$. The treatments with triple rennet concentration received even lower scores than low-fat control cheeses for texture and overall acceptability, but the differences were not statistically significant. Neither the age of the panelists nor their sex resulted in different preferences. 
Table 4. Mean $( \pm \mathrm{SD})$ of sensory attributes of FFC, LFC1C, LFC2C, and LFC3C. ${ }^{1}$

\begin{tabular}{lllll}
\hline & FFC & LFC1C & LFC2C & LFC3C \\
\hline Appearance & $4.0^{\mathrm{a}} \pm 0.8$ & $3.0^{\mathrm{b}} \pm 1.0$ & $2.7^{\mathrm{b}} \pm 1.1$ & $2.6^{\mathrm{b}} \pm 1.1$ \\
Texture & $4.0^{\mathrm{a}} \pm 1.0$ & $2.6^{\mathrm{c}} \pm 0.8$ & $3.3^{\mathrm{b}} \pm 0.6$ & $2.4^{\mathrm{c}} \pm 1.0^{\mathrm{a}}$ \\
Flavor & $4.1^{\mathrm{a}} \pm 1.0$ & $2.4^{\mathrm{b}} \pm 0.9$ & $2.7^{\mathrm{b}} \pm 1.0$ & $2.7^{\mathrm{b}} \pm 1.0$ \\
Overall acceptance & $4.3^{\mathrm{a}} \pm 0.7$ & $2.3^{\mathrm{c}} \pm 1.2$ & $3.4^{\mathrm{b}} \pm 0.8$ & $2.2^{\mathrm{c}} \pm 0.9$ \\
\hline
\end{tabular}

${ }^{\mathrm{a}, \mathrm{b}, \mathrm{c}}$ Means within the same row with different superscripts differ $(P<0.05)$.

${ }^{1} \mathrm{FFC}=$ Control, full-fat cheese; LFC1C = control, low-fat cheese with normal concentration of rennet; LFC2C = low-fat cheese with double concentration of rennet; and LFC3C = low-fat cheese with triple concentration of rennet. The sensory scale is a 5-point hedonic scale.

\section{CONCLUSIONS}

The study indicated that the reduction in fat content and rennet concentration had major effects on the microstructure, rheology, cheese-making yield, and functional characteristics of Iranian white cheese. As fat in cheese decreased, instrumental hardness parameters increased, microstructure became more compact, meltability decreased, and sensory properties of the product became undesirable. Doubling the rennet concentration in low-fat cheese improved the rheological properties and sensory impression of texture and increased the meltability, probably because of the increased rate of proteolysis. Tripling the rennet concentration resulted in a harder product, even harder than the low-fat cheese with a normal concentration of rennet, probably a result of a modified initial mode of casein micelle aggregation during gel formation and the increased rate of bond rearrangement in the formed gel. This concentration may be considered as the critical value for Iranian white cheese, in which the firming effect of the high concentration of rennet becomes dominated by the softening effect. Increasing the rennet concentration to 2 -fold the normal usage was useful for improving the textural, functional, and sensory properties of low-fat Iranian white cheese.

\section{ACKNOWLEDGMENTS}

The authors thank the Pak Dairy Company for funding this project.

\section{REFERENCES}

Abd El-Salam, M. H., and S. El-Shibiny. 1973. An electron-microscope study of the structure of Domiati cheese. J. Dairy Res. 40:113-115.

Ardö, Y., and J. Gripon. 1995. Comparative study of peptidolysis in some hard round-eyed cheese varieties with different fat contents. J. Dairy Res. 62:543-547.

Association of Official Analytical Chemists. 1997. Official Methods of Analysis. 16th ed., 3rd rev. AOAC, Arlington, VA.

Bryant, A., Z. Ustanol, and J. Steffe. 1995. Texture of Cheddar cheese as influenced by fat reduction. J. Food Sci. 60:1216-1236.

Chen, A. H., J. W. Larkin, C. J. Clark, and W. E. Irwin. 1979. Textural analysis of cheese. J. Dairy Sci. 62:901-907.
Dalgleish, D. G. 1997. The enzymatic coagulation of milk. Pages 579619 in Advanced Dairy Chemistry, 1st ed. P. F. Fox, ed. Blackie Academic \& Professional, Ltd., UK.

Dave, R. I., D. J. McMahon, C. J. Oberg, and J. R. Broadbent. 2003. Influence of coagulant level on proteolysis and functionality of Mozzarella cheese made using direct acidification. J. Dairy Sci. 86:114-126.

De Kruif, C. G. 1999. Casein micelles interactions. Int. Dairy J. 9:183-188.

Drake, M. A., W. Herrett, T. D. Boylston, and B. G. Swanson. 1996. Lecithin improves texture of reduced fat cheeses. J. Food Sci. 61:639-642.

Ehsani, M. R., S. Azarnia, and A. R. Allameh. 1999. The study of the transfer of nitrogen materials, phosphorus, calcium, magnesium, and potassium from the curd into brine during the ripening of Iranian white brined cheese. I. J. Agric. Sci. 30:11-17.

Ernstrom, C. A., W. V. Price, and A. M. Swanson. 1958. Effects of reducing rennet and adding calcium chloride on the manufacture and curing of Cheddar cheese. J. Dairy Sci. 41:61-69.

Fife, R. L., D. J. McMahon, and C. J. Oberg. 1996. Functionality of low-fat Mozzarella cheese. J. Dairy Sci. 79:1903-1910.

Foegeding, E. A., J. Brown, M. A. Drake, and C. R. Daubert. 2003. Sensory and mechanical aspects of cheese texture. Int. Dairy J. 13:585-591.

Fox, P. F. 1989. Proteolysis during cheese manufacture and ripening. J. Dairy Sci. 72:1379-1400.

Gouda, A. 1987. Degradation of casein fractions by milk clotting enzymes and the effect of sodium chloride. J. Dairy Sci. 15:15-23.

Green, M. L. 1977. Review of the progress of dairy science: Milk coagulants. J. Dairy Res. 44:159-188.

Green, M. L., D. G. Hobbs, S. V. Morant, and V. A. Hill. 1978. Intermicellar relationships in rennet-treated separated milk II. Process of gel assembly. J. Dairy Res. 45:413-422.

Guinee, T. P., and B. A. Law. 2002. Role of milk fat in hard and semihard cheeses. Pages 275-331 in Fats in Food Technology, 1st ed. K. K. Rajah, ed. Sheffield Academic Press Ltd., UK.

Holmes, D. G., J. W. Duersch, and C. A. Ernstrom. 1977. Distribution of milk clotting enzymes between curd and whey and their survival during Cheddar cheese making. J. Dairy Sci. 60:862-869.

Hort, J., and G. L. Grys. 2001. Developments in the textural and rheological properties of UK Cheddar cheese during ripening. Int. Dairy J. 11:475-481.

Hynes, E. R., C. A. Meinardi, N. Sabbag, T. Cattaneo, M. C. Candioti, and C. A. Zalazar. 2001. Influence of milk-clotting enzyme concentration on the $\alpha_{\mathrm{s} 1}$-casein hydrolysis during soft cheese ripening. J. Dairy Sci. 84:1335-1340.

International Dairy Federation. 1997. Bovine rennets: Determination of total milk clotting activity. Standard 157A. IDF, Brussels, Belgium.

Johnson, M. E., C. M. Chen, and J. J. Jaeggi. 2001. Effect of rennet coagulation time on composition, yield and quality of reduced-fat Cheddar cheese. J. Dairy Sci. 84:1027-1033.

Kahyaoglu, T., and S. Kaya. 2003. Effects of heat treatment and fat reduction on the rheological and functional properties of Gaziantep cheese. Int. Dairy J. 13:867-875. 
Katsiari, M. C., E. Alichanidis, L. P. Voutsinas, and I. G. Roussis. 2000. Proteolysis in reduced sodium Feta cheese made by partial substitution of $\mathrm{NaCl}$ and KCl. Int. Dairy J. 10:635-646.

Kindstedt, P. S., J. J. Yun, D. M. Barbano, and K. L. Larose. 1995. Mozzarella cheese: Impact of coagulant concentration on chemical composition, proteolysis, and functional properties. J. Dairy Sci. 78:2591-2597.

Koca, N., and M. Metin. 2004. Textural, melting and sensory properties of low-fat fresh Kashar cheese produced by using fat replacers. Int. Dairy J. 14:365-373.

Laloy, E., J. C. Vuillemard, M. El-Soda, and R. E. Simard. 1996. Influence of fat content of Cheddar cheese on retention and localization of starters. Int. Dairy J. 6:729-740.

Lawrence, R. C., L. K. Creamer, and J. Gilles. 1987. Texture development during cheese ripening. J. Dairy Sci. 70:1748-1760.

Lawrence, R. C., H. A. Heap, and J. Gilles. 1984. A controlled approach to cheese technology. J. Dairy Sci. 67:1632-1645.

Lomholt, S. B., and K. B. Qvist. 1997. Relationship between rheological and degree of $\kappa$-casein proteolysis during renneting of milk. J. Dairy Res. 64:541-549.

Lucey, J. A. 2002. Formation and physical properties of milk protein gels. J. Dairy Sci. 85:281-294.

Ma, L., M. A. Drake, G. V. Barbosa-Cánovas, and B. G. Swanson. 1996. Viscoelastic properties of reduced-fat and full-fat Cheddar cheeses. J. Food Sci. 61:821-823.

Madsen, J. S., and Y. Ardö. 2001. Exploratory study of proteolysis, rheology and sensory properties of Danbo cheese with different fat contents. Int. Dairy J. 11:423-431.

McKenna, B. M. 2003. Texture in Food, Volume 1: Semi-solid foods. Vood Head Publishing Ltd. and CRC Press LLC.

McMahon, D. J., R. L. Fife, and C. J. Oberg. 1999. Water partitioning in Mozzarella cheese and its relationship to cheese meltability. J. Dairy Sci. 82:1361-1369.

Metzger, L. E., and V. V. Mistry. 1995. A new approach using homogenization of cream in the manufacture of reduced fat Cheddar cheese. 2. Microstructure, fat globule distribution, and free oil. J. Dairy Sci. 78:1883-1895.

Mistry, V. V. 2001. Low fat cheese technology. Int. Dairy J. $11: 413-422$

Mohsenin, N. N. 1986. Physical Properties of Plant and Animal Materials. 2nd rev. Gordon and Breach, Science Publishers, Inc., US.

Muthukumarappan, K., Y. C. Wang, and S. Gunasekaran. 1999. Short communication: Modified Schreiber test for evaluation of Mozzarella cheese meltability. J. Dairy Sci. 82:2280-2296.

O'Keeffe, R. B., P. F. Fox, and C. Daly. 1976. Contribution of rennet and starter proteases to proteolysis in Cheddar cheese. J. Dairy Res. 43:97-107.

Paulson, B. M., D. J. McMahon, and C. J. Oberg. 1998. Influence of sodium chloride on appearance, functionality, and protein ar- rangement in nonfat Mozzarella cheese. J. Dairy Sci. 81:20532064.

Perry, D. B., D. J. McMahon, and C. J. Oberg. 1997. Effect of exopolysaccharide producing cultures on moisture retention in low fat Mozzarella cheese. J. Dairy Sci. 80:799-805.

Poduval, V. S., and V. V. Mistry. 1999. Manufacture of reducedfat Mozzarella cheese using ultrafiltered sweet buttermilk and homogenized cream. J. Dairy Sci. 8:1-9.

Rodríguez, J. 1998. Recent advances in the development of low-fat cheeses. Trends in Food Sci. Technol. 9:249-254.

Romeih, E. A., A. Michaelidou, C. G. Biliaderis, and G. K. Zerfiridis. 2002. Low-fat white-brined cheese made from bovine milk and two commercial fat mimetics: Chemical, physical and sensory attributes. Int. Dairy J. 12:525-540.

Rudan, M. A., D. M. Barbano, J. J. Yun, and P. S. Kindstedt. 1999. Effect of fat reduction on chemical composition, proteolysis, functionality, and yield of Mozzarella cheese. J. Dairy Sci. 82:661-672.

Sipahioglu, O., V. B. Alvarez, and C. Solano-Lopez. 1999. Structure, physico-chemical and sensory properties of Feta cheese made with tapioca starch and lecithin as fat mimetics. Int. Dairy J. 9:783-789.

Spangler, P. L., L. A. Jensen, C. H. Amundson, N. F. Olson, and C. G. Hill, Jr. 1991. Ultrafiltered Gouda cheese: Effects of preacidification, diafiltration, rennet and starter concentration, and time of cut. J. Dairy Sci. 74:2809-2819.

Steffe, J. F. 1996. Rheological Methods in Food Process Engineering, 2nd ed. Freeman Press, East Lansing, MI.

Tunick, M. H. 2000. Rheology of dairy foods that gel, stretch, and fracture. J. Dairy Sci. 83:1892-1898.

Tunick, M. A., E. L. Malin, P. W. Smith, J. J. Shieh, B. C. Sullivan, K. L. Mackey, and V. H. Holsinger. 1993. Proteolysis and rheology of low-fat and full-fat Mozzarella cheese prepared from homogenized milk. J. Dairy Sci. 76:3621-3628.

Ustunol, Z., K. Kawachi, and J. Steffe. 1995. Rheological properties of Cheddar cheese as influenced by fat reduction and ripening time. J. Food Sci. 60:1208-1210.

Walstra, P. 1999. Casein sub-micelles: Do they exist? Int. Dairy J. 9:189-192.

Wium, H., K. R. Kristiansen, and K. B. Qvist. 1998. Proteolysis and its role in relation to texture of Feta cheese made from ultrafiltered milk with different amounts of rennet. J. Dairy Res. 65:665-674.

Wium, H., P. S. Pedersen, and K. B. Qvist. 2003. Effect of coagulation conditions on the microstructure and the large deformation properties of fat-free Feta cheese made from ultrafiltered milk. Food Hydrocoll. 17:287-296.

Wium, H., and K. B. Qvist. 1998. Effect of rennet concentration and method of coagulation on the texture of Feta cheeses made from ultrafiltered bovine milk. J. Dairy Res. 65:653-663. 